\title{
Seizure Self-Efficacy Scale for Children with Epilepsy: Confirmatory and Exploratory Factor Analysis
}

\section{Çocuklarda Nöbet Öz-Yeterlik Ölçeği: Doğrulayıcı ve Açıklayııı Faktör Analizi}

\author{
Şerife Tutar Güven1, Mehmet Ziya Fırat2, Ayşegül Işler Dalgıç1 \\ ${ }^{1}$ Akdeniz University Faculty of Nursing, Department of Pediatric Nursing, Antalya, Turkey \\ ${ }^{2}$ Akdeniz University Faculty of Agriculture, Department of Animal Science, Antalya, Turkey
}

\begin{abstract}
Aim: In the past few years, the concept of self-efficacy in children with epilepsy has become increasingly important. This study aimed to analyze the psychometric aspects of the Turkish version of the Seizure Self-Efficacy Scale for Children.

Materials and Methods: This is a cross-sectional survey. The study data were collected using the Seizure Self-Efficacy Scale for Children and Child Introduction Form. The study sample included 166 children who were between 9 and 17 years of age. The authors assessed the reliability and construct validity of the study data using exploratory and confirmatory factor analyses (CFA).

Results: The original model was not confirmed by the CFA. The analysis tool included 15 items in two factors. Reliability analysis showed that the two factors were acceptable and valid. The tool was valid and reliable for measuring the self-efficacy of epileptic children. The factor structure was derived from and confirmed by the original tool. It was found that the Turkish version of the modified Seizure Self-Efficacy Scale for Children had excellent satisfactory psychometric aspects for a Turkish population.

Conclusion: Health professionals can present a more effective drug process and nursing care by identifying and assessing seizure self-efficacy levels in children with epilepsy, and they can make a positive contribution to disease management and the way the child deals with the disease.

Keywords: Epilepsy, self-efficacy, confirmatory factor analysis, exploratory factor analysis
\end{abstract}

ÖZ

Amaç: Son yıllarda epilepsi hastalığı olan bireylerde öz yeterlik kavramı gittikçe önem kazanmaktadır. Bu çalışmanın amacı, epilepsi hastalı̆̆ı olan çocuklarda Nöbet Öz-Yeterlik Ölçeği'nin Türkçe versiyonunun psikometrik yönlerini analiz etmektir.

Gereç ve Yöntemler: Bu çalışma kesitsel desendedir. Araştırmanın verileri Çocuklarda Nöbet Öz-Yeterlik Ölç̧eği ve Çocuk Tanıtım Formu kullanılarak toplanmıştır. Araştırmanın örneklemini 9-17 yaş arası 166 çocuk oluşturmuştur. Verilerin geçerliği ve güvenirliğinin incelenmesinde açıklayıcı ve doğrulayıcı faktör analizleri (DFA) kullanılmıştır.

Bulgular: DFA sonucunda ölçeğin geliştriildiği örneklem grubundaki faktör yapısının doğrulanmadığı belirlendi. Analiz edilen 15 maddelik ölçekte, iki faktörlü yapı belirlendi. Bu iki faktörlü yapının geçerliği ve güvenirliği yapılan analizlerle doğrulandı. Ölçeğin yeni faktör yapısı ise ölçeğin orijinalinden elde edilerek doğrulandı. Bununla birlikte Nöbet Öz-Yeterlik Ölçeği'nin iki faktörlü yapısının psikometrik analizlerinin Türk çocuklarında kabul edilebilir düzeyde olduğu ve epilepsi hastalı̆ı olan çocuklarda öz-yeterliği ölçmede geçerli güvenilir bir araç olduğu belirlendi.

Sonuç: Sağlık profesyonelleri, epilepsi hastalı̆̆ı olan çocuklarda nöbet özyeterlik düzeyini belirleyerek ve değerlendirerek daha etkili bir tedavi süreci ve hemşirelik bakımı sunabilirler, bunun sonucunda çocuğun hastalıkla baş etmesine ve hastalı̆̆ın yönetim sürecine olumlu katkı sağlayabilirler. Anahtar Kelimeler: Epilepsi, öz-yeterlik, doğrulayıcı faktör analizi, açıklayıcı faktör analizi 


\section{Introduction}

Epilepsy is one of the most common chronic illnesses of childhood and adolescence (1). It influences roughly 0.5 to $1 \%$ of all children up to the age of 16 years. The incidence of epilepsy in developing countries is almost twice as much as in developed countries (2). There are few studies conducted in Turkey aiming to ascertain the incidence and prevalence of epilepsy. Topbaş et al. (3) reported that the prevalence of childhood epilepsy in this country is between 0.8 and $1.7 \%$.

Epilepsy has an important effect on the maintenance of the individual's physical, psychological, and social well-being (4). In contrast to other chronic illnesses, epileptic seizures are unpredictable, which reduces the child's perception of controlling his/her own life remarkably (5). Therefore, there are social restrictions in the daily activities of epileptic children (6). Individuals with epilepsy may have feelings of inadequacy, fear, stigmatization, anger, and desperation, and they may show passive behaviors. These factors reduce the individual's psycho-social functions, self-efficacy, and quality of life, which may lead to self-destruction. Medical treatment and its side effects may also influence self-efficacy, ability to adjust to treatment, and the relationship between the patient and the caretaker $(7,8)$.

Self-efficacy is one of the most frequently used theories to anticipate health behavior, and it is an important equalizer in individuals with chronic illnesses (9). In coping with epilepsy, the patients' perception of self-efficacy is essential to their process of making decisions about their illness. In the management of epileptic seizures, self-efficacy is described as an individual's ability to cope with seizures in an effective way. Successful management of seizures is the principle goal in the course of the treatment of epilepsy $(7,10,11)$.

Individuals with high self-efficacy adjust better to treatment, their quality of life increases, and the frequency of seizures is reduced $(7,12)$. Moreover, high self-efficacy is correlated with a more positive attitude towards epilepsy, fewer depressive symptoms, less anxiety about having seizures, and less stigmatization. In these patients, a positive attitude towards and perception about the illness and selfcare behavior facilitate the adjustment to the management and treatment of the illness.

It is necessary to develop certain tools to analyze and measure the levels of self-efficacy in children with epilepsy in order to achieve a better disease management. There are few studies conducted in Turkey on this. The objective of our study was to examine the psychometric aspects of the Turkish version of the Seizure Self-Efficacy Scale for Children (SSES-C).

\section{Materials and Methods}

\section{Study Design}

This is a methodological study. The authors performed the validity analysis of the SSES employing confirmatory and exploratory factor analyses (EFA). Confirmatory factor analysis (CFA) is frequently used in scale development in nursing studies. However, there has been little discussion of its use in scale testing in nursing science research. CFA is a special approach of Structural Equation Modeling (SEM). SEM combines factor analysis and regression analysis, allowing the study of the causal relationships between factors using regression analysis. CFA and EFA are included in the family of factor analyses. CFA is different than EFA since EFA is used to ascertain an exploratory factor model without making a prior assumption of the association between variables. EFA investigates the structure of correlation or covariance matrices (13).

\section{Participants and Procedure}

The study population included children between the ages of 9 and 17, who were diagnosed with epilepsy, and who visited University of Health Sciences Antalya Training and Research Hospital, Akdeniz University Hospital, and Bursa Dörtçelik Children's Hospital between June 2012 and March 2013. The children had been diagnosed with epilepsy at least six months previously and did not have any other chronic disease (e.g., diabetes or cerebral palsy), or mental retardation. Consent form was filled out by all participants. The study was approved by the Akdeniz University Local Ethics Committee (approval number: B.30.2.AKD.0.20.05.05/39). The authors suggest that five to twenty times of the number of variables in the scale be included to determine the sample size in the validity and reliability analysis (14). This study did not use any sample selection method. In the light of the literature, 166 children who met the inclusion criteria were recruited to the study.

Based on the suggestions of experts, the authors reviewed the whole content of the scale and conducted a pilot study. The authors held interviews with the children in a silent environment in the pediatric neurology polyclinic of the tertiary care hospital where the study was conducted. The information forms were filled out by the authors during the interviews with the children. The pilot study was conducted with 10 children whose data were excluded from the study.

\section{Instruments}

Data in this study were collected using the Child Introduction Form and the SSES-C.

Child Introduction Form: The authors created this form based on the relevant literature (12). It included 28 questions about the socio-economic status and the illness process of the children.

The Seizure Self-Efficacy Scale for Children: This is a 5-point Likert-type scale of 15 items. All items in the scale contained positive statements. The responses to the scale items were enumerated from 1 to 5 . The scores for each item ranged between 1 and 5 and were created by dividing the total score on the instrument by the number of questions in the instrument. This instrument was created for the children between 9 and 14 years of age, had had epilepsy for at least 
six months, and had no other chronic illnesses or intellectual disability. The Cronbach's alpha coefficient of the instrument was 0.93 which indicates that the scale was quite reliable (12).

The cross-cultural validation of the instruments allows researchers to avoid the early phases of the development of a new questionnaire. This is a big advantage since it is a very long procedure. Moreover, the translation and conversion of an instrument into different languages enables us to employ the questionnaires in comparative multi-national studies. The scale was translated and back-translated to ensure its validity and reliability, along with some other aspects, for the Turkish sample. The translation and cultural conversion of the study were performed at a very initial phase (8). Reliability and validity analysis of the questionnaire were done specifically for this study since the scale did not have a Turkish version. All 15 items in the instrument were translated into Turkish by four authors (S.G., H.T., D.B., and G.M.) and the items were resolved into a completely new translated version. Then, back-translation of the items into English was blindly done, and items were checked by a bilingual Turkish scientist and a native English speaker fluent both in spoken and written Turkish and with a great deal of experience as a medical paper reviewer. Authors and the other experts discussed and agreed on the translation of each item. Moreover, the authors conducted a pilot study with bilingual individuals to determine the linguistic accuracy of the translated scale. The authors also decided that the translation was acceptable and required no revision.

\section{Statistical Analysis}

The authors encoded and scored all the items in the scale, encoded and checked all the study data, and finally analyzed it using SPSS 11.0 and statistical analysis system 7.0 statistical programs. All of the required information was collected from the participants and all the forms were completed. To be able to describe the main variables, the authors made use of descriptive statistics including means, skewness and standard deviation.

\section{Confirmatory Factor Analysis}

Using CFA, researchers ascertain the goodness of fit indices (GFI) between a model that has previously been created by a different author and the sample data in question. In this study, the authors employed the maximum likelihood estimation method to do CFA in order to confirm the exploratory model which (12) was created. The authors followed the original one-factor model and used the same model specification in this analysis. The factor variances were fixed at 1 , which provided the identification of the model.

The authors also calculated a variety of GFI to be able to measure the level of the fit. To many researchers, the standard GFI is 0.90 (15-18). The authors also used some other criteria for this calculation. Initially, the authors determined 0.90 for the GFI and 0.90 for the adjusted GFI.
Then, they evaluated how well the new model fit the data using the root mean square error of approximation (RMSEA) with a $90 \%$ confidence interval. An RMSEA value of 0.06 or less indicates an accepted model fit (15). A moderate fit would be indicated by values around 0.08 , and poor fit would be shown by values above 0.10 (19). After that the authors administered a GFI chi-square test, which included the best fit where the chi-square was statistically insignificant. Next, the authors used Bentler and Bonett's normed-fit index (NFI). The NFI values varied between 0 and 1, and an acceptable model fit to the data was shown by the 0.90 values (20). Finally, the authors used a comparative fit index (CFI) (21). Researchers usually accept a cutoff value of 0.90 for the CFI as consistent with the moderate model fit (21), and believe that a good model fit is indicated by a cutoff value which is close to 0.95 . Since the fit indices values become distorted when the distribution of the scale items is not normal, the study also reported the skewness values.

\section{Exploratory Factor Analysis}

When the observed factor structure does not fit with the theoretical structure, then the EFA can be employed to improve the model. In order to describe an applicable factor structure, the authors did an EFA in the second phase of the analysis. They also did an EFA to identify the factor sub-scales of the 15 items in the scale employing a principal component method with varimax rotation. The study determined the number of sub-scales that had Eigen values bigger than 1.0 for retaining the factor. However, the study retained items with factor loads greater than or equal to 0.40 (including the values rounded to 0.40 ), and also retained those that loaded on only one factor. The authors excluded from the scale items that did not fit these criteria one by one. They did the factor analyses over and over again until they found a solution that made all the scale items meet all of the criteria. Cronbach's alpha was used to evaluate the internal consistency reliability and the structure of the new factors.

\section{Results}

Table I illustrates the descriptive statistics such as mean, standard deviation and skewness values of the study sample. The authors evaluated the study data using the skewness values by univariate normality. The table indicates that mean skewness value was -0.976 [(range $=-2.386-(-0.290)$ ], and none of the items was showing a bigger skewness value than the cutoffs of $|3|$ that was suggested (22). The univariate normality of the items were advocated by these findings.

\section{Confirmatory Factor Analysis}

The study tested a one-factor model according to the original conceptualization of SSES-C. The criteria of model fit evaluation are presented in Table II. Some of these criteria were not acceptable for a good fit. However, the others showed an acceptable or nearly acceptable model fit. These points can also be seen in Table II. According to the study 
data, an adequate model fit was revealed by the CFA, and this model fit was only based on Bentler's CFI criterion (0.9028). There was a moderate fit based on GFI (0.8704), adjusted GFI (0.8271); RMSEA (0.0776) and NFI (0.8249). However, there was only one fit index that indicated poor fit: $\chi^{2}(90)=179.329, p=0.0001$. The authors could not acquire an acceptable fit from any of the fit statistics. There was only one fit statistic that showed a nearly reasonable model fit. Four other fit statistics showed a moderate fit with the model. Thus, the authors determined that since the CFA failed to confirm the original factor structure, it was necessary to improve the fit between the model and the data and to use the EFA to modify the model.

\section{Exploratory Factor Analysis}

In order to analyze the 15 items in the scale, the authors used the maximum likelihood extraction method and also made use of a varimax rotation. They also identified two

\begin{tabular}{|l|l|l|}
\hline \multicolumn{3}{|l|}{ Table I. Summary statistics and comparison of mean item (n=166) } \\
\hline Item & Mean \pm SD & Skewness \\
\hline $\begin{array}{l}\text { I can manage my seizure condition by making } \\
\text { good choices about which activities I do. }\end{array}$ & $3.23 \pm 1.51$ & -0.290 \\
\hline $\begin{array}{l}\text { I can manage my seizure condition so I don't } \\
\text { have to miss school or other activities. }\end{array}$ & $3.89 \pm 1.34$ & -0.926 \\
\hline $\begin{array}{l}\text { I can keep from doing things that might make } \\
\text { my seizure condition worse, even if I get } \\
\text { pressure from my friends. }\end{array}$ & $4.08 \pm 1.24$ & -1.223 \\
\hline $\begin{array}{l}\text { I can manage my seizure condition when I } \\
\text { am at school. }\end{array}$ & $3.65 \pm 1.55$ & -0.732 \\
\hline $\begin{array}{l}\text { I can manage my seizure condition even if I } \\
\text { am angry or sad. }\end{array}$ & $3.18 \pm 1.47$ & -0.294 \\
\hline $\begin{array}{l}\text { I can manage my seizure condition even if } \\
\text { there are things to worry about in my family. }\end{array}$ & $3.61 \pm 1.49$ & -0.635 \\
\hline $\begin{array}{l}\text { I can manage my seizure condition even if I am } \\
\text { at a friend's, on vacation, or on a school trip. }\end{array}$ & $3.84 \pm 1.47$ & -0.837 \\
\hline $\begin{array}{l}\text { I can talk to the doctor or nurse if I have } \\
\text { questions about my seizure condition. }\end{array}$ & $4.12 \pm 1.28$ & -1.434 \\
\hline $\begin{array}{l}\text { I can keep from being afraid after a seizure in } \\
\text { order to manage the situation. }\end{array}$ & $3.54 \pm 1.54$ & -0.572 \\
\hline $\begin{array}{l}\text { I can talk to my parents if I have problems with } \\
\text { my seizure condition. }\end{array}$ & $4.55 \pm 1.01$ & -2.386 \\
\hline $\begin{array}{l}\text { I can manage my seizure condition by making } \\
\text { sure I get enough rest. }\end{array}$ & $4.08 \pm 1.14$ & -1.193 \\
\hline $\begin{array}{l}\text { I can manage my seizure condition by staying } \\
\text { away from things that can make it worse. }\end{array}$ & $3.92 \pm 1.27$ & -1.065 \\
\hline $\begin{array}{l}\text { I can manage my feelings about my seizure } \\
\text { condition by reminding myself of my good } \\
\text { qualities. }\end{array}$ & $3.66 \pm 1.44$ & -0.768 \\
\hline $\begin{array}{l}\text { I can do the things my doctor told me to do to } \\
\text { manage my seizure condition. }\end{array}$ & $4.30 \pm 1.09$ & -1.679 \\
\hline $\begin{array}{l}\text { I can manage my seizure condition because I } \\
\text { can handle any problems it can cause. }\end{array}$ & $3.56 \pm 1.29$ & -0.608 \\
\hline SD: Standard deviation & & \\
\hline
\end{tabular}

factors that had eigenvalues above 1.00. The numbers of factors to be retained and rotated were determined using the scree test. This test also recommended a two-factor solution. The authors examined many other criteria to determine the number of factors. These criteria included Tucker and Lewis's reliability coefficient (TLC) (23), which takes values between 0 and 1.0 with a higher TLC value indicating more acceptable reliability like Akaike's information criterion (AIC) (24); and Schwarz's Bayesian criterion (SBC) (25). It is accepted that the best factor solution is the factor number that produces the smallest value of AIC and SBC or the largest value of TLC. The authors rotated and examined many factor solutions to decide on a right factor solution which is theoretically meaningful and fits the retention rules. In the end, the authors selected the two-factor solution since all three criteria were met by this solution. Compared to the other factor solutions, the four-factor and three-factor solutions in particular, AIC and SBC reached their smallest values in their two common factors, and TLC also reached its highest value (TLC=0.958) in these factors. For this reason, it is certain that the two-factor solution is the best for these data. After the authors decided on the two-factor solution, they arranged the factor loads from the greatest to the smallest. This arrangement is shown in Table III. All of the items were kept in the original 15-item measure of the scale according to the criteria that were determined beforehand. The authors assumed that all items were loaded on one single factor since the factor loads of the items were equal to or below 0.40. In the end, the EFA generated a 15-item measurement which had a two-factor solution. Then, the authors interpreted each item by examining their contents and coefficient patterns. These two factors were respectively classified as "self-management of seizures" and "the influence of the environment in the management of seizure." The authors eventually used Cronbach's alpha coefficient to determine the internal consistency reliability

Table II. Goodness of fit indices for the Seizure Self-Efficacy Scale for Children factor model

\begin{tabular}{|l|l|}
\hline Index & Children with epilepsy \\
\hline GFI & 0.8704 \\
\hline GFI adjusted for degrees of freedom (AGFI) & 0.8271 \\
\hline Chi-square & 179.3290 \\
\hline Chi-square DF & 90 \\
\hline Pr >chi-square & $<0.0001$ \\
\hline RMSEA estimate & 0.0776 \\
\hline RMSEA 90\% lower confidence limit & 0.0609 \\
\hline RMSEA 90\% upper confidence limit & 0.0941 \\
\hline Bentler's comparative fit index & 0.9028 \\
\hline Bentler \& Bonett's (1980) non-normed index & 0.8867 \\
\hline Bentler \& Bonett's (1980) NFI & 0.8249 \\
\hline $\begin{array}{l}\text { GFI: Goodness of fit index, AGFI: Adjusted goodness of fit index, RMSEA: Root mean } \\
\text { square error of approximation, NFI: Normed-fit index, DF: Degrees of freedom }\end{array}$ \\
\hline
\end{tabular}


of both scales. There was a scale homogeneity that varied between 0.63 and 0.89 . Thus, the subscales that were identified by EFA had internal consistency. Total SSES-C's

\begin{tabular}{|c|c|c|}
\hline Items of SSES-C & $\begin{array}{l}\text { Self- } \\
\text { management } \\
\text { of seizures } \\
\text { (F1) }\end{array}$ & $\begin{array}{l}\text { The influence of } \\
\text { the environment } \\
\text { in the } \\
\text { management of } \\
\text { seizures } \\
\text { (F2) }\end{array}$ \\
\hline $\begin{array}{l}\text { (1) I can manage my seizure condition } \\
\text { by making good choices about which } \\
\text { activities I do. }\end{array}$ & 0.60 & \\
\hline $\begin{array}{l}\text { (2) I can manage my seizure condition } \\
\text { so I don't have to miss school or other } \\
\text { activities. }\end{array}$ & 0.51 & \\
\hline $\begin{array}{l}\text { (4) I can manage my seizure condition } \\
\text { when I am at school. }\end{array}$ & 0.69 & \\
\hline $\begin{array}{l}\text { (5) I can manage my seizure condition } \\
\text { even if I am angry or sad. }\end{array}$ & 0.75 & \\
\hline $\begin{array}{l}\text { (6) I can manage my seizure condition } \\
\text { even if there are things to worry about } \\
\text { in my family. }\end{array}$ & 0.78 & \\
\hline $\begin{array}{l}\text { (7) I can manage my seizure condition } \\
\text { even if I am at a friend's, on vacation, } \\
\text { or on a school trip. }\end{array}$ & 0.76 & \\
\hline $\begin{array}{l}\text { (9) I can keep from being afraid after } \\
\text { a seizure in order to manage the } \\
\text { situation. }\end{array}$ & 0.43 & \\
\hline $\begin{array}{l}\text { (11) I can manage my seizure condition } \\
\text { by making sure I get enough rest. }\end{array}$ & 0.69 & \\
\hline $\begin{array}{l}\text { (12) I can manage my seizure condition } \\
\text { by staying away from things that can } \\
\text { make it worse. }\end{array}$ & 0.49 & \\
\hline $\begin{array}{l}\text { (13) I can manage my feelings about my } \\
\text { seizure condition by reminding myself } \\
\text { of my good qualities. }\end{array}$ & 0.59 & \\
\hline $\begin{array}{l}\text { (15) I can manage my seizure condition } \\
\text { because I can handle any problems it } \\
\text { can cause. }\end{array}$ & 0.75 & \\
\hline $\begin{array}{l}\text { (3) I can keep from doing things that } \\
\text { might make my seizure condition } \\
\text { worse, even if I get pressure from my } \\
\text { friends. }\end{array}$ & & 0.56 \\
\hline $\begin{array}{l}\text { (8) I can talk to the doctor or nurse } \\
\text { if I have questions about my seizure } \\
\text { condition. }\end{array}$ & & 0.67 \\
\hline $\begin{array}{l}\text { (10) I can talk to my parents if I have } \\
\text { problems with my seizure condition. }\end{array}$ & & 0.56 \\
\hline $\begin{array}{l}\text { (14) I can do the things my doctor } \\
\text { told me to do to manage my seizure } \\
\text { condition. }\end{array}$ & & 0.76 \\
\hline Cronbach's alfa & 0.89 & 0.63 \\
\hline Variance explained \% & 32.79 & 16.87 \\
\hline Cumulative variance & 32.79 & 49.67 \\
\hline
\end{tabular}

alpha coefficient was quite high (0.90). This value shows that the internal reliability was excellent since it far exceeded the accepted limit, which was 0.70 . This also implies that the questions in the scale were adequate for the Turkish culture.

\section{Discussion}

In the past few years, the context of self-efficacy in individuals with epilepsy has become increasingly important. The perceived self-efficacy of the patient is quite important in the management of epilepsy to be able to understand the process of decision-making. In our study, we aimed to examine the psychometric aspects of the Turkish version of the SSES-C. The ages of the children and adolescents in the sample ranged between 9 and 17. Their average age was $13.46 \pm 2.57$.

Current research indicates that the factor structure of the SSES-C was examined for the first time in this study with a relatively large Turkish sample that includes children with epilepsy when the CFA did not confirm the original factor structure. In the authors' opinion, this study will make remarkable contributions to the relevant literature when the SSES-C is adapted to Turkish culture. It is essential that the psychometric aspects of the scale be used for measurement and gaining information in terms of understanding the nature of the attitude of individuals with epilepsy towards selfefficacy.

As indicated by the results of the CFA, the factor structure, which was derived from and confirmed by US patients, was not confirmed by the Turkish sample. For this reason, the US and Turkish samples had different dimensionality in their beliefs in self-efficacy, as shown by the findings of the CFA. In this study, the authors employed EFA to gain a new modified factor structure for the Turkish sample. This operation aimed to obtain accurate cross-cultural comparisons. The EFA generated a new factor structure, or model with the two separate dimensions of self-efficacy in Turkish culture. This situation is different from the original onedimension factor structure, which claims that every factor can be taken into account independently when scoring the SSES-C. It is generally accepted that this model represents the distinctiveness of two dimensions of self-efficacy. The subscale "self-management of seizures" includes the items that explain how a child can control or manage epileptic seizures on his or her own (e.g. "I can manage my seizure condition by selecting my activities correctly"). The other subscale includes the statements that focus on the effect of the environment on seizure management, rather than on the child's individual control (e.g. "I can speak to my physician or a nurse when I have a question about my seizure condition"). The authors established the factor structure of SSES-C for the sample that included children with epilepsy. Then, the internal consistency of the instrument was determined. According to the findings of this study, the modified factor structure of the SSES-C has desired psychometric aspects for the Turkish sample. The study used the Cronbach's alpha coefficient to 
determine the reliability of the instrument. The estimated alpha of the SSES-C (0.89) was slightly lower than the one reported in the original study, which was conducted with a US sample (0.93) (12), but it was still higher than the result (0.85) of other studies (26). Eventually, the study findings had a strong reliability and a solid internal consistency.

\section{Study Limitations}

This study had several limitations. In the relevant literature, the SSES-C is the only tool available to examine the self-efficacy of children with epilepsy. However, there are no foreign studies which aimed to validate the SSES-C by the administration of CFA and EFA. Moreover, there are also no other studies conducted in Turkey to examine the self-efficacy of children with epilepsy. Therefore, the authors recommend that further studies be conducted to test the SSES-C with different samples.

\section{Conclusion}

In terms of the factor structure of the SSES-C, there are certain differences between the US and Turkish samples. According to the study results, the best and most effective use of the measurement will be performed by summing the subscale scores instead of the total score. This finding is consistent with the theoretical opinion that multidimensionality is the best way to conceptualize self-efficacy. This tool was proved to be valid and reliable to measure self-efficacy in children with epilepsy. For this reason, the authors suggest that researchers use the SSES-C when it is necessary to measure the self-efficacy of epileptic children. The children are capable of evaluating their own self-efficacy, which makes it easier to manage the illness and adjust it to the treatment. Moreover, the awareness of health professionals working with children who have epilepsy can be increased by the application of SSES-C. To conclude, this study proves that SSES-C can be applied to make use of the differences between the sub-samples included both in a single structure and in different cultures.

\section{Acknowledgments}

The authors obtained via e-mail, the consent of Joan K. Austin, the creator of the SSES-C, to translate it into Turkish. They also obtained the approval of their Institutional Review Board's Ethics Committee.

The authors would like to thank all participants in this study. This research was supported by the Akdeniz University, Scientific Research Projects Management Unit.

\section{Ethics}

Ethics Committee Approval: The study was approved by the Akdeniz University Local Ethics Committee (approval number: B.30.2.AKD.0.20.05.05/39).

Informed Consent: Written consent was obtained from the children and their parents who participated in the study.
Peer-review: External and internal peer-reviewed.

\section{Authorship Contributions}

Concept: Ş.T.G., M.Z.F., A.I.D., Design: Ş.T.G., M.Z.F., A.I.D., Data Collection or Processing: S.T.G., Analysis or Interpretation: S.T.G., M.Z.F, Literature Search: S..T.G., M.Z.F., Writing: S.T.G., M.Z.F., A.I.D.

Conflict of Interest: No conflict of interest was declared by the authors.

Financial Disclosure: The authors declared that this study received no financial support.

\section{References}

1. Rodgers CC. The Child with Cerebral Dysfunction. In: Hockenberry MJ, Wilson D, (eds). Wong's Nursing Care of Infants and Children, 10th ed. Elsevier/Mosby, 2015;1425-83.

2. Epilepsy Action Australia. Facts and Statistics About Epilepsy [cited 2015 September 17] Available from: URL: https:// www.epilepsy.org.au/resources/for-media/facts-statisticsabout-epilepsy Date of Access: 09/17/2015.

3. Topbaş M, Özgün Ş, Sönmez MF, et al. Epilepsy prevalence in the 0-17 age group in Trabzon, Turkey. Iran J Pediatr 2012;22:344-50.

4. Dharmadhikari AS, Sinha VK. Psychiatric comorbidity in children with epilepsy: a cross-sectional 5 years rural prevalence study. J Neurosci Rural Pract 2017;8:179-84.

5. Tutar Güven Ş, Işler A. Importance of Seizure Self-efficacy in Children with Epilepsy for Disease Management. Epilepsi 2014;20:103-6.

6. Wohlrab GC, Rinnert S, Bettendorf U, et al. Famoses: a modular educational program for children with epilepsy and their parents. Epilepsy Behav 2007;10:44-8.

7. Chen HF, Tsai YF, Lin YP, Shih MS, Chen JC. The relationships among medicine symptom distress, self-efficacy, patientprovider relationship, and medication compliance in patients with epilepsy. Epilepsy Behav 2010;19:43-9.

8. Tutar Güven Ş, Işler A. Validity and reliability of the seizure self-efficacy scale for children with epilepsy. Noro Psikiyatr Ars 2015;52:47-53.

9. Amtmann D, Bamer AM, Cook KF, Askew RL, Noonan VK, Brockway JA. University of Washington self-efficacy scale: a new self-efficacy scale for people with disabilities. Arch Phys Med Rehabil 2012;93:1757-65.

10. Wagner JL, Smith G, Ferguson PL, Horton S, Wilson E. Hopelessness model of depressive symptoms in youth with epilepsy. J Pediatr Psychol 2009;34:89-96.

11. Wagner JL, Smith G, Ferguson PL, van Bakergem G, Hrisko S. Pilot study of an integrated cognitive-behavioral and self-management intervention for youth with epilepsy and caregivers: Coping Openly and Personally with Epilepsy (COPE). Epilepsy Behav 2010;18:280-5.

12. Caplin D, Austin JK, Dunn DW, Shen J, Perkins S. Development of a self- efficacy scale for children and adolescents with epilepsy. Children's Health Care 2002;31:295-309.

13. Kääriäinen $M$, Kanste $O$, Elo $S$, Pölkki T, Miettunen J, Kyngäs $\mathrm{H}$. Testing and verifying nursing theory by confirmatory factor analysis. J Adv Nurs 2011;1163-72. 
14. Stevens JP. Applied Multivariate Statistics for the Social Sciences. 4th ed. Hamilton, New Jersey, Printing Company, 2002;325-81.

15. Hu LT, Bentler PM. Cutoff criteria for fit indexes in covariance structure analysis: conventional criteria versus new alternatives. Structural Equation Modeling 1999;6:1-55.

16. McRae RR, Zonderman $A B$, Costa $P T$, Bond $M H$ Paunonen SV. Evaluating replicability of factors in the revised NEO personality inventory: confirmatory factor analysis versus pro-crustean rotation. J Pers Soc Psychol 1996;70:552-66.

17. Vassend O, Skrondal A. Validation of the NEO Personality Inventory and the five-factor model. Can findings from exploratory and confirmatory factor analysis be reconciled? European Journal of Personality 1997;11:147-66.

18. McDonald RP, Marsh HW. Choosing a multivariate model: noncentrality and goodness of fit. Psychological Bulletin 1990;107:247-55
19. Browne MW, Cudeck R. Alternative ways of assessing model fit. In: Bollen KA, Long JS, eds. Testing Structura Equation Models Sage. Newbury Park CA, 1993;136-60.

20. Bollen KA. Structural equations with latent variables. New York, Wiley, 1989;80-148.

21. Bentler PM. Comparative fit indices in structural models. Psychological Bulletin 1990;107:238-46.

22. Kline RB. Principles and practice of structural equation modeling. New York, Guilford Press, 2005;124-49.

23. Tucker LR, Lewis C. A reliability coefficient for maximum likelihood factor analysis. Psychometrika 1973;38:1-10.

24. Akaike H. Factor analysis and AIC. Psychometrika 1987;52:317-32.

25. Schwarz G. Estimating the dimension of a model. The Annals of Statistics 1978:6:461-4.

26. Wagner JL, Smith G, Ferguson P. Self-efficacy for seizure management and youth depressive symptoms: Caregiver and youth perspectives. Seizure 2012;21:334-9. 